\title{
IMPLEMENTASI MEDIA PERMAINAN ULAR TANGGA PADA MATERI TATA NAMA SENYAWA TERHADAP HASIL BELAJAR SISWA KELAS X SMA NEGERI 10 BANJARMASIN
}

\author{
The Implementation of Snake and Ladder Game Media on \\ Nomenclature of Compounds Topic Toward Students' Learning Outcome in \\ Class X SMA Negeri 10 Banjarmasin
}

Yulia Rahma, Gusti Hadiatus Solehah, Mohan Taufiq Mashuri

Program Studi Pendidikan Kimia Fakultas Keguruan dan Ilmu Pendidikan

Universitas Islam Kalimantan (Uniska) Muhammad Arsyad Al Banjari, Banjarmasin

*e-mail: yuliarahma24@gmail.com

\begin{abstract}
Abstrak. Penelitian ini bertujuan untuk mengetahui hasil belajar siswa pada materi tata nama senyawa dengan menggunakan media permainan ular tangga. penelitian ini menggunakan metode Pre-tes Post-test Control Group Design dengan penelitian diambil dua kelas yaitu, pada kelas X-2 sebagai kelas kontrol dan X-4 sebagai kelas eksperimen. Populasi penelitian adalah siswa kelas X semester genap SMA Negeri 10 Banjarmasin tahun ajaran 2016/2017. Teknik pengumpulan data yang digunakan metode tes, dokumentasi dan wawancara. Teknik analisis data data menggunakan uji normalitas, uji homogenitas, uji t dan uji $\mathrm{N}$-Gain. Berdasarkan hasil penelitian pada materi tata nama senyawa kelas X SMA Negeri 10 Banjarmasin bahwa terdapat perbedaan hasil belajar yang signifikan antara siswa yang menggunakan media pembelajaran permainan ular tangga dengan yang tidak menggunakan media permainan ular tangga yaitu $t_{\text {hitung }}>t_{\text {tabel }}(4.792>2.000)$ maka $\mathrm{H}_{0}$ ditolak dan $\mathrm{H}_{\mathrm{a}}$ diterima. Sehingga dapat disimpulkan bahwa terdapat perbedaan yang signifikan hasil belajar siswa pada materi tata nama senyawa yang menggunakan media permainan ular tangga. Hal ini membuktikan bahwa implementasi media pemainan ular tangga pada materi tata nama senyawa efektif dalam meningkatkan hasil belajar siswa pada kelas X SMA Negeri 10 Banjarmasin
\end{abstract}

Kata Kunci: Hasil belajar, media permainan ular tangga, tata nama senyawa

Abstract. This study attempted to know the result of student learning on nomenclature of compounds topic by using snake and ladder game media. This research used pre-test post-test control group design by taking two classes as sample, class $X-2$ as the controlled class and X-4 as the experimented class. Research population was students of class $X$ in SMA Negeri 10 Banjarmasin on the second half of semester in academic year 2016/2017. Data collection techniques used were test, documentation and interview. Data analysis techniques were using normality test, homogeneity test, $t$ test and the n-gain. Based on the research done to nomenclature of compounds topic in class X SMA Negeri 10 Banjarmasin, there were significant differences in learning outcome between students who used snake and ladder game learning media and those who did not use snake and ladder game with tcalculated $>$ table $(4.792>2,000)$ so then $H_{0}$ was rejected and $H_{a}$ was accepted. Therefore, it can be concluded that there were significant differences in students' learning outcome on nomenclature of compounds topic by using snake and ladder game learning media. This proved 
that the implementation of snake and ladder game media on nomenclature of compounds topic was effective to improve students' learning outcomes in class $X$ SMA Negeri 10 Banjarmasin.

Keywords: learning outcome, nomenclature of compounds, snake and ladder game media

\section{PENDAHULUAN}

Ilmu kimia merupakan salah satu bidang kajian Ilmu Pengetahuan Alam (IPA). Mata pelajaran kimia menjadi sangat penting kedudukannya dalam masyarakat karena kimia selalu berada di sekitar kita dalam kehidupan sehari-hari. Kimia merupakan mata pelajaran yang mempelajari mengenai materi dan perubahan yang terjadi di dalamnya. Perubahan yang terjadi ditandai dengan perubahan susunan struktur, perubahan sifat, perubahan suhu, dan perubahan energi. Dalam mata pelajaran kimia SMA berisi konsepkonsep yang cukup sulit untuk dipahami siswa, karena menyangkut reaksi-reaksi kimia dan hitungan-hitungan serta menyangkut konsep-konsep yang bersifat abstrak.

Dalam pembelajaran guru lebih banyak berperan sebagai informasi bagi siswa. Materi-materi yang penting dicatatkan oleh guru dipapan tulis, siswa cenderung pasif dalam pembelajaran. Sebaiknya materi pelajaran tidak begitu saja ditransfer oleh guru ke siswa tetapi harus dikontraksi di dalam pikiran siswa dengan cara melibatkan secara langsung. Salah satunya penyampaian materi pelajaran kepada siswa yaitu dengan menciptakan suatu media pembelajaran yang dapat membantu keterlaksanaan suatu metode. Media pembelajaran merupakan alat bantu yang dipergunakan guru untuk menyampaikan materi pelajaran kepada siswa. Dalam pembelajaran digunakan media pembelajaran sebagai suatu pola atau cara terstruktur yang diterapkan dalam pembelajaran dengan penggunaan berbagai sumber daya (guru) untuk mencapai kompetensi yang ada dalam pembelajaran. Hal ini menunjukkan bahwa penggunaan media dalam kegiatan pembelajaran sangat perlu karena untuk mempermudah proses pembelajaran sehingga dapat mencapai hasil yang optimal. Dalam pembelajaran digunakan media pembelajaran sebagai suatu pola atau cara terstruktur yang diterapkan dalam pembelajaran dengan penggunaan berbagai sumber daya (guru) untuk mencapai kompetensi yang ada dalam pembelajaran. Hal ini menunjukkan bahwa penggunaan media dalam kegiatan pembelajaran sangat perlu karena untuk mempermudah proses pembelajaran sehingga dapat mencapai hasil yang optimal. Media pembelajaran apabila digunakan secara tepat, sangat berguna baik bagi guru maupun siswa. Bagi guru, media dapat dijadikan pedoman dan acuan bertindak yang sistematis dalam pelaksanaan pembelajaran. Bagi siswa, dapat mempermudah dan mempercepat memahami isi pembelajaran, karena setiap media pembelajaran dirancang untuk mempermudah proses belajar siswa. Proses pembelajaran akan lebih mudah tercapai tujuannya apabila seorang guru mampu menggunakan media pembelajaran dengan baik. Oleh karena itu, guru harus kreatif dalam menciptakan media baru yang dapat digunakan untuk mempermudah siswa dalam menerima materi yang akan diajarkan.

Penerapan media yang digunakan dalam penelitian ini media permainan ular tangga yang harus dilakukan tidak sebatas memperbaiki kelemahan media yang sudah ada. Hidrokarbon merupakan materi yang tidak hanya bersifat hafalan saja akan tetapi memerlukan pemahaman yang mendalam. Materi Hidrokabon meliputi tatanama, sifat senyawa karbon, keisomeran, dan reaksi sederhana senyawa karbon. Pada materi 
Hidrokarbon terdapat sub bab tentang tata nama senyawa yang mana pada sub materi tata nama siswa diarahkan untuk menyebutkan nama senyawa hidrokarbon. Dalam penamaan senyawa hidrokarbon siswa harus dapat mengingat urutan penamaan, nama cabang, dan nama rantai utama senyawa hidrokarbon. Dengan memahami konsep tentang tata nama senyawa akan memudahkan siswa dalam mempelajari materi selanjutnya seperti seperti minyak bumi, penamaan senyawa, rumus molekul, struktur molekul, dan reaksi suatu senyawa. Oleh karena itu diperlukan pembelajaran yang yang memudahkan siswa untuk memahami materi Hidrokarbon.maka digunakan permainan papan seperti ular tangga kegiatan belajar akan menjadi lebih menyenangkan dan bervariasi sehingga siswa dapat lebih memahami materi tata nama senyawa.

Berdasarkan informasi dari guru kimia SMAN 10 Banjarmasin bahwa kegiatan pembelajaran masih berpusat pada guru, dengan menggunakan media molymood siswa kurang aktif dalam pelajaran sehingga, diharapkan dengan menerapkan media permainan ular tangga dapat mendorong siswa lebih aktif dalam mengikuti pelajaran sehingga dapat meningkatkan hasil belajar siswa.

Hasil observasi terdahulu yang berkaitan dengan pembelajaran IPA yaitu hasil pengamatan dan pembahasan diperoleh bahwa dengan penerapan model talking stick berbantua media ular tangga untuk meningkatkan motivasi dan hasil belajar IPA, didapat hasil persentase rata-rata motivasi belajar siswa pada siklus I sebesar $69,78 \%$ dan siklus II sebesar $84,67 \%$, persentase rata-rata hasil belajar IPA aspek afektif pada siklus I sebesar $65,4 \%$ dan siklus II sebesar $80 \%$, persentase rata-rata hasil belajar IPA aspek psikomotorik pada siklus I sebesar 69,58 dan siklus II sebesar 81,67\%. Ini berarti bahwa penerapan model pembelajaran talking stick berbantuan media ular tangga dapat meningkatkan motivasi dan hasil belajar IPA siswa Kelas IV SD Negeri 5 Dauhwaru Kecamatan Jembran Kabupaten Jembrana tahun pelajaran 2015/2016.

Dari hasil observasi penelitian yang berkaitan dengan pembelajaran matematika, yaitu media permainan ular tangga dapat meningkatkan hasil belajar kelas III SDN Caturanom Kecamatan Parakan Kabupaten Temanggung. Hasil tes siswa pada siklus I sebesar 39,13\%, siklus II 65,22\% dan siklus III sebesar 86,96\%. Yang dibuktikan dengan adanya peningkatan kemampuan siswa dari sesudah penerapan media permainan ular tangga yaitu siklus I sebanyak 10 siswa, siklus II sebesar 15 siswa dan siklus III sebesar 20 siswa yang memenuhi KKM dengan nilai (60).

Adapun hasil observasi yang juga dilakukan pada pembelajaran bahasa arab, yaitu hasil belajar kelas IV Madrasah Ibtidaiyah Nurul Jadid Kolomayan Kabupaten Blitar, didapat hasil analisis setiap siklus semangat siswa semakin meningkat. Media pembelajaran permainan ular tangga dapat meningkatkan penguasaan kosa kata bahasa arab siswa pada awal diadakan tindakan rata-rata nilai tes siswa hanya 51,7, kemudian pada siklus I nilai rata-rata tes siswa meningkat menjadi 58,1. Peningkatan penguasaan kosa kata bahasa arab siswa sebesar $12,37 \%$. Pada tindakan siklus II rata-rata nilai tes siswa menjadi 66,3 dan peningkatan penguasaan kosa kata meningkat menjadi $14,11 \%$. Pada siklus II nilai rata-rata hasil tes siswa menjadi $77,2 \%$ dan peningkatan penguasaan kosa kata sebesar $16,44 \%$.

Hasil observasi yang didapat pada penelitian pembelajaran IPS menggunakan media ular tangga, diketahui hasilnya diketahui dari N-Gain adanya perbandingan peningkatan yaitu berkurangnya siswa yang N-Gainnya rendah, yaitu pada siklus I dari 19 siswa dengan persentase $47,59 \%$, sedangkan pada siklus II menjadi 4 siswa dengan 
persentase $10,00 \%$. Mengkatnya siswa yang N-Gainnya sedang, yaitu pada siklus I dari 13 siswa dengan persentase $32,50 \%$, sedangkan pada siklus II menjadi 14 siswa dengan persentase $35,00 \%$. Meningkatnya siswa yang N-Gainnya tinggi, yaitu pada siklus I 8 siswa dengan persentase $20,00 \%$, sedangkan pada siklus II menjadi 22 siswa dengan persentase $55,00 \%$. Selain itu terdapat peningkatan rata-rata pre-tes siklus I dan pre-tes siklus II yaitu rata-rata pre-tes siklus I 42,50 dan rata-rata pre-tes siklus II 49,25, sedangkan rata-rata pos-tes siklus I 65,63 sedangkan rata-rata pos-tes siklus II 81,50. Peningkatan rata-rata N-Gain siklus I 0,40 meningkat pada siklus II menjadi 0,64. Ini berarti pelaksanaan pendekatan permainan ular tangga dapat meningkatkan hasil belajar siswa pada materi pembelajaran ilmu pengetahuan sosial kelas VII.

Keberhasilan siswa dalam belajar dapat diketahui dari hasil belajar yang diperoleh oleh siswa. Pada proses belajar mengajar prestasi merupakan bagian penting untuk mengukur pencapaian kompetensi. Hasil belajar diartikan sebagai tingkat keberhasilan siswa dalam mempelajari materi pelajaran di sekolah yang dinyatakan skor yang diperoleh dari hasil tes mengenal sejumlah materi pelajaran tertentu. Berdasarkan hal tersebut, maka perlu dilakukan suatu penelitian mengenai implementasi media permainan ular tangga pada materi tata nama senyawa terhadap hasil belajar siswa kelas X SMA Negeri 10 Banjarmasin.

\section{METODE PENELITIAN}

Berdasarkan latar belakang yang ada, jenis penelitian ini adalah Quasi Experimental atau eksperimen semu. Quasi Experimental adalah suatu desain eksperimental yang memungkinkan peneliti mengendalikan variabel secara penuh. Desain peneltian menggunakan Pre-tes Post-test Control Group Design. Dalam desain ini, terdapat dua kelompok yang dipilih secara tidak random atau tidak secara acak. Data diperoleh dari pre-test dan posttes yang dilakukan di awal dan akhir penelitian untuk mengetahui hasil belajar siswa. Bentuk desain penelitian ini yaitu Nonequevalent Control Group Design. Penelitian ini dilaksanakan di Sekolah SMA Negeri 10 Banjarmasin. Populasi adalah keseluruhan objek penelitian, jadi populasi pada penelitian ini adalah siswa kelas X SMA Negeri 10 Banjarmasin.

Sampel adalah sebagian atau wakil populasi yang diteliti. Sampel dalam kelas X-4 sebagai kelas eksperimen dan X-2 sebagai kelas kontrol. Variabel yang digunakan dalam penelitian ini yaitu variabel bebas (independent) dan variabel terikat (dependent). Variabel bebas merupakan variabel yang dapat diubah-ubah, dimanipulasi, diukur dan diamati untuk diketahui hubungan (pengaruhnya) dengan variabel lain. Dalam penelitian ini yang menjadi variabel bebasnya adalah media permainan ular tangga. Variabel terikat merupakan variabel yang muncul akibat manipulasi variabel bebas. Dalam penelitian ini yang menjadi variabel terikatnya adalah hasil belajar siswa. Teknik pengumpulan data yang digunakan metode tes, dokumentasi dan wawancara. Teknik analisis data data menggunakan uji normalitas, uji homogenitas, uji t dan uji N-Gain.

\section{HASIL DAN PEMBAHASAN}

Hasil uji coba instrumen bertujuan untuk mengetahui kelayakan perangkat pembelajaran yang dilakukan untuk soal hasil belajar yaitu uji valididtas, uji reliabilitas, uji daya pembeda dan taraf kesukaran. Dari hasil uji validitas didapat 8 soal yang valid dan 32 yang tidak valid dari 40 soal yang diujikan. Soal yang tidak valid tidak bisa 
digunakan dan soal yang valid bisa digunakan untuk soal hasil belajar. Hasil uji reliabilitas dari 40 soal dengan rumus K-R 20 didapat hasil 0.583 dengan kriteria reliabilitas sedang. Uji daya beda dengan kriteria cukup ada 2 dan baik ada 6 dari 8 soal yang valid.uji taraf kesukaran dengan 8 soal memiliki kriteria sedang yaitu soal yang memiliki tingkat kesukaran seimbang, artinya soal tersebut tidak terlalu mudah dan tidak terlalu sukar. Uji taraf kesukaran dengan 8 soal memiliki kriteria sedang yaitu soal yang memiliki tingkat kesukaran seimbang, artinya soal tersebut tidak terlalu mudah dan tidak terlalu sukar.

Tabel 1 Hasil Pretes dan Posttes kelas Eksperimen dan Kelas Kontrol

\begin{tabular}{lllll}
\hline & Pretes & \multicolumn{3}{l}{ Posttes } \\
\cline { 2 - 5 } Nilai Tertinggi & Eksperimen & Kontrol & Eksperimen & Kontrol \\
\cline { 2 - 5 } Nilai Terendah & 50 & 50 & 100 & 87.5 \\
Rata-rata & 12.5 & 25 & 62.5 & 50 \\
Selisih pretes-postes & 25 & 32.143 & 75 & 64.73 \\
\hline
\end{tabular}

Berdasarkan data dari nilai pretes didapat nilai rata-rata yaitu 25 pada kelas eksperimen dan nilai rata-rata pada kelas kontrol 32.143. Adapun nilai rata-rata posttes yaitu 75 pada kelas eksperimen sedangkan pada kelas kontrol didapat nilai 64.73. Adanya perbedaan nilai pretes dan posttes kemungkinan merupakan adanya perbedaan perlakuan pada kelas eksperimen dan kontrol tersebut, diperoleh perbedaan 10.27 untuk kelas eksperimen dan untuk kelas kontrol 7.143. Uji normalitas bertujuan untuk mengetahui apakah data dari kedua kelompok berdistribusi normal atau tidak. Hasil uji Normalitas pretes dan posttes dapat dilihat pada tabel 4.4.

Tabel 2 Hasil Uji Normalitas

\begin{tabular}{lllll}
\hline & Kelas Eksperimen & & Kelas Kontrol & \\
\hline & Pretes & Posttes & Pretes & Posttes \\
\cline { 2 - 5 } $\mathrm{L}_{0}$ & 0.1421 & 0.14 & 0.156 & 0.1668 \\
$\mathrm{~L}_{\text {tabel }}$ & 0.173 & 0.173 & 0.173 & 0.173 \\
Ket & Normal & Normal & Normal & Normal \\
\hline
\end{tabular}

Dari data yang didapat uji normalitas pretes pada kelas eksperimen didapat $\mathrm{L}_{0}$ yaitu 0.1421 dan pada kelas kontrol 0.156 dengan taraf nyata $\alpha=0.05$, dapat dilihat dari tabel uji Liliefors yaitu 0.173 maka pada kelas eksperimen $\mathrm{L}_{0}<\mathrm{L}_{\text {tabel }}(0.1421<0.173)$ dan pada kelas kontrol $\mathrm{L}_{0}<\mathrm{L}_{\text {tabel }}(0.156<0.173)$ sehingga data siswa pada uji normalitas pretes berdistribusi normal pada kelas eksperimen dan kelas kontrol.

Hasil uji normalitas posttes pada kelas eksperimen dan kelas montrol yaitu 0.14 dan 0.1668 dengan taraf nyata $\alpha=0.05$ yaitu 0.173 , maka uji normalitas posttes pada kelas eksperimen yaitu $\mathrm{L}_{0}<\mathrm{L}_{\text {tabel }}(0.14<0.173)$ dan pada kelas kontrol $\mathrm{L}_{0}<\mathrm{L}_{\text {tabel }}(0.1668$ $<0.173$ ), sehingga data siswa pada uji normalitas posttes berdistribusi normal pada kelas eksperimen dan kelas kontrol. Uji homogenitas pada pretes dapat dilihat dari tabel 4.9. Pada perhitungan uji homogenitas pretes pada kelas eksperimen dan kelas kontrol didapat $F_{\text {hitung }} 1.323$ dengan $F_{\text {tabel }} 1.95$ dengan $\alpha=0.05$, maka diperoleh $F_{\text {hitung }}<F_{\text {tabel }}$ 
sehingga $\mathrm{H}_{0}$ diterima atau homogen ini berarti data pretes pada kelas eksperimen dan kelas kontrol mempunyai varian yang homogen.

Tabel 3 Hasil Uji Homogenitas Pretes

\begin{tabular}{lcccc}
\hline Kelas & Db & SD $^{\mathbf{2}}$ & F $_{\text {hitung }}$ & F $_{\text {tabel }}$ \\
\hline Eksperimen & 24 & 11.4108 & 1.323 & 1.95 \\
Kontrol & 27 & 8.626 & & \\
\hline
\end{tabular}

Pada tabel 3 data uji homogenitas posttes pada kelas eksperimen dan kelas kontrol yaitu $F_{\text {hitung }} 1.1147$ dengan $F_{\text {tabel }} 1.95$ dengan $\alpha=0.05$ diperoleh $F_{\text {hitung }}<F_{\text {tabel }}$ (1.1147 <1.95) sehingga $\mathrm{H}_{0}$ diterima atau data homogen. Ini berarti data posttes pada kelas eksperimen dan kelas kontrol mempunyai varian yang homogen.

Tabel 4 Hasil Uji Homogenitas Posttes

\begin{tabular}{lcccc}
\hline Kelas & Db & SD $^{\mathbf{2}}$ & F $_{\text {hitung }}$ & F $_{\text {tabel }}$ \\
\hline Eksperimen & 24 & 11.4108 & 1.1147 & \multirow{2}{*}{1.95} \\
Kontrol & 27 & 10.236 & & \\
\hline
\end{tabular}

Uji t dilakukan apabila uji normalitas dan uji homogenitas pada pretes dan posttes di kelas eksperimen dan kelas kontrol berdistribusi normal dan homogen. Hasil perhitungan uji t pretes dapat dilihat pada tabel 5 berikut.

Tabel 5 Uji t pretes

\begin{tabular}{lcc}
\hline Kelas & Eksperimen & Kontrol \\
\hline $\mathbf{N}$ & 25 & 28 \\
Db & 24 & 27 \\
Mean & 25 & 32.14 \\
S & 11.411 & 8.625 \\
thitung & & -2.599 \\
ttabel & \multicolumn{2}{c}{ Tidak berbeda signifikan } \\
Keterangan & \multicolumn{2}{c}{} \\
\hline
\end{tabular}

Berdasarkan dari data uji t pretes pada kelas kontrol dan kelas eksperimen dengan $\mathrm{t}_{\text {hitung }}-2.599$ dan $\mathrm{t}_{\text {tabel }} 2.00$ dengan $\mathrm{db}=51$ dan $\alpha=0.05$, sehingga $\mathrm{t}_{\text {hitung }}<\mathrm{t}_{\text {tabel }}(-2.559<$ 2.000), maka tidak dapat perbedaan yang signifikan antara kelas eksperimen dan kelas kontrol sebelum dilakukan perlakuan yang berbeda pada kedua keles. Uji t posstets adalah data tes terakhir dapat dilihat dari tabel 6 berikut.

\section{Tabel 6 Uji t Posttes}

\begin{tabular}{|c|c|c|}
\hline Kelas & Eksperimen & Kontrol \\
\hline $\mathbf{N}$ & 25 & 28 \\
\hline Db & 24 & 27 \\
\hline Mean & 75 & 64.73 \\
\hline $\mathbf{S}$ & 11.411 & 10.236 \\
\hline$t_{\text {hitung }}$ & \multicolumn{2}{|c|}{4.792} \\
\hline ttabel & \multicolumn{2}{|c|}{2.000} \\
\hline
\end{tabular}


Berdasarkan data dari uji $\mathrm{t}$ posttes didapat $\mathrm{t}_{\text {hitung }}=4.792$ dan $\mathrm{t}_{\text {tabel }}=2.000$ dengan $\mathrm{db}=51$ dan $\alpha=0.05$, diperoleh $\mathrm{t}_{\text {hitung }}>\mathrm{t}_{\text {tabel }}(4.792>2.000)$ maka $\mathrm{H}_{0}$ ditolak dan $\mathrm{H}_{\mathrm{a}}$ diterima. Pada uji t posttes dapat disimpulkan bahwa adanya perbedaan hasil belajar siswa yang signifikan setelah dilaksakan perlakuan berbeda pada kedua kelas tersebut pada materi tata nama senyawa yang menggunkan media permainan ular tangga.

Pada uji t posttes bertujuan untuk menguji hipotesis penelititan apakah diterima atau ditolak dimana: $\mathrm{H}_{0}$ yaitu tidak terdapat perbedaan hasil belajar siswa yang signifikan antara kelas eksperimen dan kelas kontrol. $\mathrm{H}_{\mathrm{a}}$ yaitu adanya perbedaan hasil belajar siswa yang signifikan antara kelas eksperimen dan kelas kontrol. Hasil belajar siswa dari pretes dan posttes dihitung menggunakan $\mathrm{N}$-Gain untuk mengetahui sejauh mana siswa mengalami peningkatan hasil belajar setelah mengikuti pembelajaran.Adapun kategori $\mathrm{N}$-Gain yang diperoleh dari nilai rata-rata $\mathrm{N}$-Gain dari kelas eksperimen dan kelas kontrol dapat dilihat pada tabe 4.10.

Tabel 7 Kategori N-Gain Kelas Eksperimen dan Kelas Kontrol

\begin{tabular}{lll}
\hline Kelas & Rata-rata N-Gain & Kategori \\
\hline Eksperimen & 0.65 & Sedang \\
Kontrol & 0.57 & Sedang \\
\hline
\end{tabular}

Dari tabel 7, kelas eksperimen mempunyai nilai rata-rata N-Gain yaitu 0.65 dan kelas kontrol 0.57. Ini berarti nilai rata-rata $\mathrm{N}-$ Gain kelas eksperimen lebih tinggi dari pada nilai rata-rata $\mathrm{N}$-Gain kelas kontrol, maka kelas eksperimen mengalami peningkatan hasil belajar setelah mendapat pelajaran dengan menggunakan media permainan ular tangga.

Dalam penelitian ini dilakukan uji coba instrumen pada kelas XI IPA 1 untuk mengetahui kelayakan soal yang akan diberikan dengan menggunakan uji validitas, uji reliabilitas, uji daya beda dan uji taraf kesukaran. Pada uji validitas didapat 8 soal yang valid dan 32 soal yang tidak valid dari 40 soal yang diujikan. Kemungkinan sebagian siswa sudah lupa pada pelajaran tata nama senyawa atau sebagian siswa tidak serius dalam mengerjakan soal yang diberikan sehingga hanya mendapatkan 8 yang valid dari 40 soal yang diujikan.

Setelah melakukan uji validitas soal yang valid diuji reliabilitas agar bisa dapat dipercaya sebagai alat pengumpulan data. Pada uji reliabilitas didapatkan hasil 0.583 berdistribusi reliabilitas sedang sehingga dapat digunakan untuk sebagai alat pengumpulan data. Setelah dilakukan uji reliabilitas selanjutnya diuji lagi menggunakan daya beda.

Daya beda bertujuan untuk mengetahui seberapa jauh kemampuan suatu butir soal tersebut membedakan antara siswa yang berkemampuan tinggi dengan siswa yang berkemampuan rendah. Dari 8 soal yang diujikan didapat 6 soal yang baik dan 2 soal yang cukup dengan jumlah siswa kelas atas 12 dan jumlah siswa kelas bawah 18 . Setelah melakukan uji daya beda maka selanjutnya diuji dengan uji taraf kesukaran.

Uji taraf kesukaran untuk dari indeks kesukaran, dari hasil yang didapat semua soal berkriteria sedang. Jika soal yang terlalu mudah tidak merangsang siswa untuk memecahkannya, sedangkan soal yang terlalu sukar dapat menyebabkan siswa cepat putus asa. Jadi soal yang baik adalah soal yang memiliki tingkat kesukaran seimbang, 
artinya soal tersebut tidak terlalu mudah dan tidak terlalu sukar sehingga 8 soal yang telah diujikan dapat diujikan dalam penelitian sebagai alat pengumpulan data.

Pembelajaran dalam penelitian ini menerapkan media permainan ular tangga dan mengetahui pengaruh pembelajaran menggunakan media permainan ular tangga pada materi pokok tata nama senyawa di SMAN 10 Banjarmasin. Penelitian ini menggunakan metode eksperimen semu (quasi experiment), yaitu penelitian dalam dua kelas yang dibedakan menjadi kelas eksperimen dan kelas kontrol dimana X-2 menjadi kelas kontrol dan X-4 menjadi kelas eksperimen.

Pada kelas eksperimen diterapkan media permainan ular tangga dan pada kelas kontrol menggunakan pembelajaran tanpa menggunakan media pembelajaran. Pada penelitian ini diperoleh hasil belajar dari pretes dan posttes untuk mengukur hasil belajar siswa pada kedua kelas tersebut.

Dari data pretes pada penelitian ini terdapat perbedaan nilai pretes anatara kedua kelas tersebut yaitu kelas kontrol lebih tinggi nilai pretes dari pada kelas eksperimen pada kelas kontrol yaitu 32.14, sedangkan pada eksperimen 25.00. Ini menunjukan bahwa kemampuan awal dari kedua kelas tidak jauh berbeda. Dari hasil uji normalitas pada kelas kontrol dan eksperimen berdistribusi normal dan pada uji homogenitas pada kelas eksperimen dan kontrol mempunyai varian yang sama atau berdistribusi homogenitas sama. Pada uji $t$ diperoleh $t_{\text {hitung }}<t_{\text {tabel }}(-2.599<2.000)$ ini berarti $\mathrm{H}_{0}$ diterima yang artinya tidak ada perbedaan antara hasil belajar kelas kontrol dan kelas eksperimen sebelum pembelajaran.

Dalam pembelajaran kelas eksperimen diberi perlakuan yang berbeda dengan kelas kontrol. Pada kelas eksperimen menggunakan pembelajaran dengan media permainan ular tangga sedangkan pada kelas kontrol tanpa bantuan media permainan ular tangga. Setelah melakukan pembelajaran maka dilakukan tahap akhir yaitu posttes pada kedua kelas untuk melihat apakah ada pengaruh hasil belajar pada kedua kelas setelah dilakukannya pembelajaran menggunakan media permainan ular tangga dan yang tidak menggunakan permainan luar tangga.

Dari hasil nilai posttes terdapat perbedaan antara kelas kontrol dan kelas eksperimen pada hasil belajar. Pada kelas kontrol nilai posttes 64.73 sedangkan pada kelas eksperimen nilai posttes yang didapat yaitu 75, sehingga kelas eksperimen lebih tinggi dari kelas kontrol ini menunjukan bahwa adanya kenaikan hasil belajar pada kelas eksperimen. Pada uji normalitas untuk kelas eksperimen dan kelas kontrol berdistribusi normal dan untuk uji homogenitas memiliki varian yang sama. Dari hasil uji t diperoleh uji $t_{\text {hitung }}>t_{\text {tabel }}(4.792>2.000)$, ini berarti Ha diterima sehingga adanya perbedaan hasil belajar pada kelas ekaperimen dan kelas kontrol. Setelah diperlakukan pada kelas eksperimen menggunakan media permainan ular tangga dan pada kelas kontrol tidak menggunakan pembelajaran dengan media permainan ular tangga terdapat perbedaan hasil belajar dari kedua kelas tersebut.

Dari peningkatan hasil belajar kedua kelas tersebut dapat dilihat dari hasil pretes dan posttes yang diperoleh dari kedua kelas tersebut. Peningkatan pada kelas eksperimen yaitu $10.27 \%$ dan pada kelas kontrol yaitu $7.143 \%$, maka adanya kenaikan hasil belajar siswa pada kelas eksperimen. Ini karena adanya perlakuan pembelajaran pada kelas eksperimen. Penelitian ini sejalan dengan penelitian yang dilakukan oleh Widiastuti (2015) yaitu menggunakan media permainan ular tangga dapat meningkatkan hasil belajar siswa. 


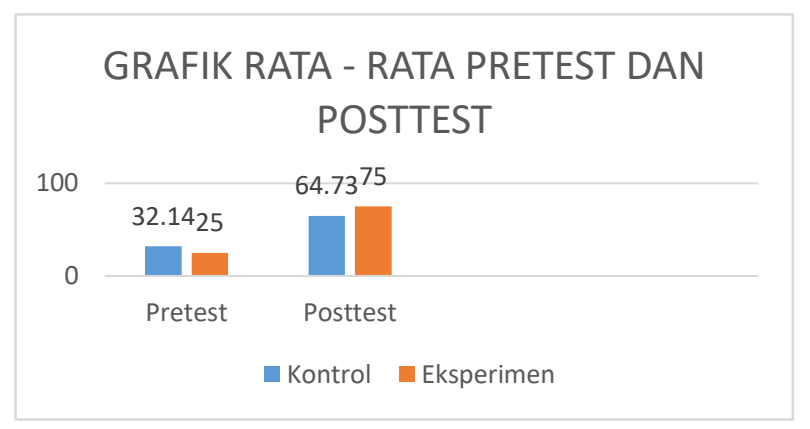

Gambar 1. Grafik rata-rata pretes dan posttes

Peningkatan hasil belajar antara kelas eksperimen dengan kelas kontrol dilihat dari nilai rata-rata $\mathrm{N}$-Gain pretes dan posttes masing-masing kelas. Perbandingan nilai rata-rata $\mathrm{N}-\mathrm{Gain}$ dapat dilihat pada grafik gambar 2

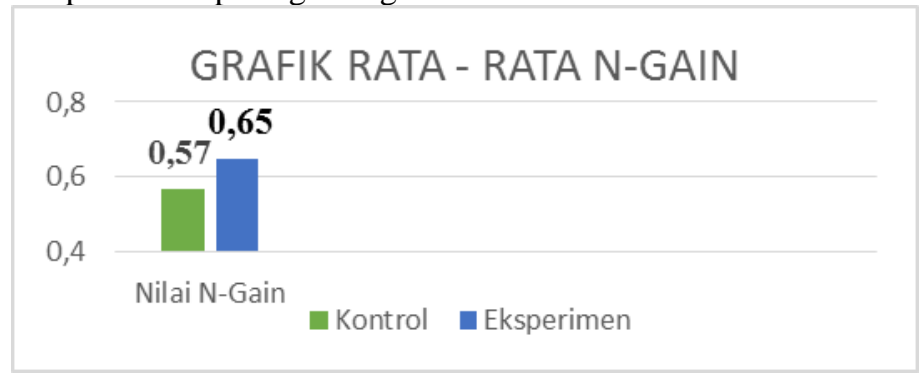

Gambar 2. Rata-rata nilai N-Gain

Berdasarkan hasil nilai pretes, posttes dan n-gain kelas eksperimen dan kontrol terdapat perbedaan hasil belajar pada materi yang diajarakan pada kelas eksperimen dan kelas kontrol, sehingga penerapan pembelajaran menggunakan media permainan ular tangga dapat membuat hasil belajar siswa meningkat dari pada kelas kontrol yang tidak menggunakan media pembelajaran ular tangga.

Dalam pembelajaran menggunakan media permainan ular tangga juga memiliki kendala yaitu memerlukan banyak waktu menjelaskan kepada siswa aturan permainan dan saat permainan dimulai sehingga diperlukan banyak waktu agar bisa bermain.

Berdasarkan uraian diatas, dapat ditarik kesimpulan bahwa kelas eksperimen memiliki kenaikan hasil belajar dibandingkan dengan kelas kontrol. Ini berarti pembelajaran menggunakan media permainan ular tangga lebih efektif dari pada pembelajaran tanpa menggunakan media pemainan ular tangga.

\section{SIMPULAN}

Berdasarkan hasil penelitian dan pembahasan dapat disimpulkan bahwa penerapan media permainan ular tangga efektif meningkatkan hasil belajar siswa pada materi tata nama senyawa dikelas X SMA Negeri 10 Banjarmasin, terdapat perbedaan 
hasil belajar antara kelas yang menerapkan media permainan ular tangga dengan kelas yang tidak menerapkan media pembelajaran dan peningkatan hasil belajar yang menggunakan media permainan ular tangga adalah $10.27 \%$ sedangkan kelas yang tidak menerapkan media permainan ular tangga yaitu $7.143 \%$.

Berdasarkan hasil penelitian dapat disarankan peneliti lanjutan dapat dikembangkan lagi, dengan menggunakan media permainan ular tangga ataupun media lainnya, selain terhadap hasil belajar siswa juga dapat dikembangkan terhadap kegiatan lainnya seperti keaktifan, pemahaman konsep, kemampuan pemecahan masalah dan kemampuan komunikasi dan media permainan ular tangga salah satu alternatif yang dapat digunakan sehari-hari pada pelajaran kimia khususnya pada materi tata nama senyawa.

\section{DAFTAR RUJUKAN}

Akmalia, D, Jumiati, Sari, M. 2011. Peningkatan Hasil Belajar Siswa Dengan Menggunakan Model Numbered Heads Together (NHT) Pada Materi Gerak Tumbuhan.

Arikunto, S. (2012). Dasar-dasar Evaluasi Pendidikan Edisi 2. Bumi Aksara, Jakarta.

Hernanto, A., Ruminten. (2009). Kimia I untuk SMA/MA Kelas X. Jakarta. Pusat Perbukuan Dapertemen Pendidikan Nasional.

Maisyaroh, I. (2014). Penerapan Metode Permainan Ular Tangga (SNAKES LEDDER) Untuk Meningkatkan Hasil Belajar Siswa Pada Materi Pelajaran IPS. Skripsi. Jakarta: Universitas Islam Negeri (UIN).

Mertler, C. (2011). Action Research Mengembangkan Sekolah Memberdayakan Guru. Yogyakarta: Pustaka Pelajar.

Nugroho, A. (2013). Pengembangan Media Pembelajaran Fisika Menggunakan permainan Ular tangga Ditinjau dari motivasi belajar siswa. Skripsi : Universitas Sebelas Maret Surakarta.

Riduwan. (2012). Belajar Mudah Penelitian Untuk Guru-karyawan Peneliti Pemula. Bandung : Alfabeta.

Rizki, L. (2015). Penerapan Media Pembelajaran Permainan Ular Tangga Untuk Meningkatkan Penguasaan Kosa Kata Bahasa Arab Siswa Kelas IV Madrasah Ibtidaiyah Nurul Jadid Kolomayan Kabupaten Blitar. Skripsi. Malang: Universitas Islam Negeri Maulana Malik Ibrahim Malang.

Solichin, Moh. (2016). Media Pembelajaran dengan Ular Tangga (Online), (http://solikin11.blogspot.com/2012/05/media-pembelajaran-dengan ulartangga.html) diakses 21 November 2016.

Sudjana, N. (2014). Penilaian Hasil Proses Belajar Mengajar. Bandung : Pt Remaja Rosdakarya.

Sugiyono. (2016). Metode Penelitian Pendidikan (Pendekatan Kuantitatif, Kualitatif dan $R \& D)$. Bandung : Alfabeta. 